\title{
Effect of Crop Rotation and Straw Application in Combination With Mineral Nitrogen Fertilization on Soil Carbon Sequestration in the Thyrow Long-term Experiment Thy_D5
}

Bärbel Kroschewski ( $\square$ b.kroschewski@hu-berlin.de )

Humboldt-Universität zu Berlin https://orcid.org/0000-0002-7725-4485

Christel Richter

Humboldt-Universität zu Berlin

Michael Baumecker

Humboldt-Universität zu Berlin

Timo Kautz

Humboldt-Universität zu Berlin

\section{Research Article}

Keywords: Long-term experiment, rotation, straw application, mineral nitrogen fertilization, yield, soil organic carbon

Posted Date: January 19th, 2022

DOI: https://doi.org/10.21203/rs.3.rs-1217910/v1

License: (9) This work is licensed under a Creative Commons Attribution 4.0 International License.

Read Full License 


\section{Abstract}

\section{Purpose}

The aim of study was to quantify the temporal change of soil organic carbon content in relation to agricultural management for a dry sandy arable soil and to derive the $\mathrm{C}$ sequestration potential.

\section{Methods}

We analyzed data from a long-term field experiment with three crop rotations of different cereal proportions, with two levels of straw application (removal/return) in combination with four mineral nitrogen rates $\left(40 \ldots 160 \mathrm{~kg} \mathrm{ha}^{-1} \mathrm{yr}^{-1}\right)$. Treatments are arranged in a two-factorial block design with two replicates for each rotation. During the 24-year study period, grain and straw yield of two cereal test crops and soil organic carbon content in topsoil were determined annually from each plot.

\section{Results}

Soil organic carbon content was positively influenced by removing non-cereal crops from the rotation and - to a smaller extent - by straw application. Increasing mineral $\mathrm{N}$-fertilization from $40 \mathrm{~kg} \mathrm{ha}^{-1} \mathrm{yr}^{-1}$ to higher rates increased grain yield of rye but not barley, increased straw yield of both cereals more, with no effect of higher straw yields on soil organic carbon content.

\section{Conclusion}

Despite the overall soil organic carbon content of the sandy soil under study is comparatively low, the results indicate that agricultural management has a relevant impact on soil carbon stocks. Straw return contributes to carbon sequestration even in rotations with a low potential for reproduction of organic matter. High mineral $\mathrm{N}$-fertilization is not an adequate measure to sequester carbon.

\section{Introduction}

Soil carbon content (SOC) has been studied so far largely in terms of its positive effects on soil properties, crop yield, and yield stability. Recognizing that changes in SOC stocks are climate-relevant, there is an additional focus on assessing agricultural soils for their potential as organic carbon pool (Peoplau et al. 2020). For Germany, the first agricultural soil inventory at national scale identified average soil organic carbon (SOC) contents for croplands on mineral soils of $17.6 \pm 8.9 \mathrm{~g} \mathrm{~kg}^{-1}$ at $0-10 \mathrm{~cm}$ depth and $15.5 \pm 8.2 \mathrm{~g} \mathrm{~kg}^{-1}$ at 10-30 cm depth. The derived SOC stock values were $61 \pm 25 \mathrm{Mg} \mathrm{ha}^{-1}$ for 0-30 cm as the current reference depth in the greenhouse gas inventory (Peoplau et al. 2020). Regularly resampling is needed to detect und quantify changes in SOC.

Long-term experiments (LTE), which have been conducted for decades, provide continuous information on long-term effects of different management systems on crop and soil characteristics (Körschens et al. 2014). An essential criterion for the usability of data from LTEs is long periods of time without significant 
modifications in treatments and experimental conditions (Körschens 2021; Rasmussen et al. 1998; Reckling et al. 2021; Stumpf et al. 2021).

Considerations on humus require a distinction between permanent (long-term stable, uninvolved in mineralization process) and nutrient humus (Körschens 2021). Körschens (2021) reported for 68 European LTEs that the total humus carbon content ranges from $0.15-2.29 \%$ and that the part of permanent humus carbon content is mainly between $0.32 \%$ (sandy soil) and $1.46 \%$ (black soil). Observing permanent humus values requires LTEs with plots of bare fallow over a long period of time. Nutrient humus carbon content that can be influenced by management measures was reported to be $0.29 \%$ on average across the 68 LTEs.

SOC content is rarely stable, it can accumulate, but it can also be degraded. In temperate climates, SOC changes occur very slowly and can be observed only after years (Johnston et al. 2017; Körschens et al. 2014; Poulton et al. 2018). The direction of change in SOC content toward a particular site-specific 'equilibrium' level depends largely on the initial SOC level and on the specific cropping system that are applied constantly over a long period of time (Johnston et al. 2017; Körschens et al. 2014). Due to frequent alterations of the cultivation measures, it is unrealistic to achieve an equilibrium state of SOC content under agricultural practices.

The influences of climate change are superimposed by fertilization, crop rotation, tillage and other agricultural management measures (Körschens et al. 2014). For instance, crop rotations with tuber crops can decrease SOC content as compared with cereal monoculture (Kaiser et al. 2007), root crops and fallow increase soil aeration, which favours soil microbial decomposition of organic matter (Johnston et al. 2017).

For mineral soils without significant groundwater influence, the quantity of annual C-input by organic fertilizers and plant residues is a central driver of changes in SOC stocks (Peoplau et al. 2020). Straw return can increase SOC content despite the effect on SOC content is lower compared to farmyard manure (Zhao et al., 2009). Mineral fertilization has a relatively low impact due to the rapid mineralization of plant and root residues (Körschens 2021). Johnston et al. (2017) reported that only $5 \%$ of the added organic carbon over a 70 -year period was retained in the soil and $95 \%$ was lost.

Increasing SOC aims to improve soil functioning and quality for more sustainable agriculture; but in recent years, the discussion has focused more on the contribution of soils to carbon sinks to mitigate climate change.

For a sandy loam, increasing SOC content by including grass or grass + clover leys in the rotation or by applying high amounts of farmyard manure is possible, but only for a limited period towards a new equilibrium (Johnston et al. 2017). Poulton et al. (2018) concluded from 16 LTEs in south-east United Kingdom that it is unrealistic to increase $\mathrm{SOC}$ as a major contribution to climate change mitigation and instead suggested promoting practices that increase SOC, even slightly, to preserve and improve the functioning of soils. 
The potential of sandy soils to sequester significant amounts of carbon is questionable, especially because they generally have a lower SOC content than fine-textured soils. Based on data from a long-term field experiment, our aim was to quantify the temporal change of SOC content in the topsoil in relation to crop rotation design, straw application, and mineral nitrogen fertilization for a dry sandy soil and to derive the carbon sequestration potential.

\section{Materials And Methods}

\section{Data base}

The experimental site Thyrow (experimental station of the Humboldt-Universität zu Berlin, Germany) is located south of Berlin (379609 E, 5790564 N; ETRS89, UTM Zone 33). The soil type is a Retisol (IUSS Working Group WRB 2015) from glacial deposits covered by a thick sandy layer of more than $0.7 \mathrm{~m}$. The tillage horizon $(0-28 \mathrm{~cm})$ is characterized by a sandy soil texture with an average clay content of $27 \mathrm{~g} \mathrm{~kg}^{-1}$ and silt content of $142 \mathrm{~g} \mathrm{~kg}^{-1}$. The soil is free of carbonates, the $\mathrm{pH}$ value is kept at an optimum value of $5.4-5.8$ by liming.

The long-term experiment D5 was established in 1937 to compare different types of potassium fertilizers in crop rotations with $50 \%$ cereals. Besides two zero $\mathrm{K}$ treatments, 66 or $100 \mathrm{~kg} \mathrm{~K} \mathrm{ha}^{-1} \mathrm{yr}^{-1}$ were applied with different types of fertilizers. The potassium treatments differed only slightly, so this experimental question was abandoned in 1971 and a new experimental question was introduced using the same plots but modified treatments. With a short transition period from 1974 to 1975, the LTE has been running as Crop rotation, straw and mineral-N fertilisation trial Thy_D5 since 1976. Both treatment factors straw application and mineral nitrogen fertilization have been tested in three four-course rotations with one crop per year. The rotations differ in the percentage of cereals in the crop rotation: Rotation 1 involves $50 \%$ cereals (beets - spring barley - winter rye - maize for silage), rotation 2 comprises $75 \%$ cereals (beets spring barley - winter rye - winter rye), and rotation 3 includes 100\% cereals (winter barley - spring barley - winter rye - oat). The second and third crops per rotation are identical for all rotations, they serve as test crops (Payne 2015).

Eight treatments result from the combination of two levels of straw application and 4 levels of nitrogen. In addition, there are two further treatments which, unlike the others, did not received potassium until 1971 (zero K treatments) and are tested without straw return of test crops in combination with the third $\mathrm{N}$ level from 1976 onward. The treatment factors are described in detail in Table 1. For each rotation, the treatments are arranged in a two-factorial randomized complete block design with two special additional treatments and two replicates (Fig. 1).

Soil tillage measures such as stubble cultivation, ploughing, and seedbed preparation before sowing were comparable for all crops in all rotations. The sowing dates for the two test crops were generally the last decade of March for spring barley and the last decade of September for winter rye. Only beets, which are included in crop rotation 1 and 2, had further mechanical agrotechnical measures that have a strong 
impact on soil structure, namely mechanical weed control three times and the harvesting procedure. Herbicides and fungicides were applied according to best practice. Spring barley and winter rye were usually harvested end of the second half of July. Grain yield and straw yield (dry matter Mg ha-1) per plot of both were used for data analysis.

Recording of SOC content ( $\mathrm{g} \mathrm{kg}^{-1}$ soil) started in 1973, so that in addition to the annual plot values from 1976 onwards, initial values from the changeover period up to 1975 are also available. Soil samples for SOC determination have been taken in the topsoil $(0-20 \mathrm{~cm})$ after harvest in autumn from each plot in each year. The organic carbon was determined by wet combustion (Springer and Klee, 1955).

From 1999 onwards, the trial was modified with respect to the crop sequence, and the mineral $\mathrm{N}$ amounts were reduced. Both had a substantial influence on yields and SOC values. In addition, a change in laboratory method for SOC determination resulted in an unreliable time series in the early years of the second trial period after 1999 and additional years are needed for a longer data series. Therefore, only the first experimental period 1976 - 1999 was used for the present analysis, resulting in 6 complete cycles over 24 years. This meets the minimum 20-year period for studying long-term effects (Rasmussen et al. 1998), and for the second period, this is not yet the case for SOC.

The climate at the experimental site is classified as semi-continental. Information on mean daily air temperature $\left({ }^{\circ} \mathrm{C}\right)$ and total precipitation $(\mathrm{mm})$ for the annual growing seasons from September of the preceding year to October of harvest year are shown for the study period in Fig. 2. The corresponding 30year long-term averages of the reference period $1971-2000$, the mean daily air temperature of $8.87^{\circ} \mathrm{C}$ and the total precipitation of $497 \mathrm{~mm}$ per growing season, are plotted as reference line. At Thyrow site, presummer drought is particularly pronounced. Therefore, the graph also includes the precipitation total for the months of May and June, which are most critical for cereal yields.

From the SOC content, soil organic carbon stock $\left(\mathrm{Mg} \mathrm{ha}^{-1}\right)$ was derived for topsoil 0-20 $\mathrm{cm}$ (sampling depth) using dry bulk density $(\mathrm{BD})$ values per treatment calculated by $B D=1.628 \cdot e^{-0.084 \cdot S O C}$ (Zimmer et al. 2014).

\section{Statistical analysis}

Data analysis was performed separately for each crop rotation as treatments were randomly allocated to plots per rotation independently. The effect of straw application (S10, S11) in combination with mineral $\mathrm{N}$ fertilization ( $\mathrm{N} 1 \ldots \mathrm{N} 4)$ on grain and straw yield of the two test crops as well as on SOC was analyzed with the following statistical model per rotation over all 6 crop rotation cycles:

$$
y_{i j k l}=\mu+\alpha_{i}+\beta_{j}+(\alpha \beta)_{i j}+C y c_{k}+(C y c \alpha)_{i k}+(C y c \beta)_{j k}+(C y c \alpha \beta)_{i j k}+\rho_{l}+e_{i j k l}
$$

where $y_{i j k l}$ is the observed value for ith straw level, $\mathrm{j}$ th nitrogen level, $\mathrm{k}$ th cycle and Ith block; $\mu$ the population mean; $a_{i}$ the fixed effect of straw level $i(i=1,2) ; \beta_{j}$ the fixed effect of nitrogen level $j(j=1, \ldots, 4)$;

$(a \beta)_{i j}$ the fixed interaction effect of both treatment factors; $C_{1} c_{k}$ the fixed effect of Cycle $k(k=1, \ldots, 6)$; 
further all fixed interaction effects between Cycle and both treatment factors as well as their interaction; $\rho_{\mid}$the fixed effect of block I $(I=1,2)$; and $e_{i j k l}$ the random error of the $i j \mid$ th plot in cycle $k$.

In addition, the comparison of all 10 treatments in SOC was performed with the following model per rotation:

$$
y_{i k l}=\mu+\tau_{i}+C y c_{k}+(C y c \tau)_{i k}+\rho_{l}+\varepsilon_{i k l}
$$

where $\mathrm{y}_{\mathrm{ikl}}$ is the observed value for $\mathrm{i}$ th treatment, $\mathrm{k}$ th cycle and Ith block; $\mu$ the population mean; $\tau_{\mathrm{i}}$ the fixed effect of treatment $\mathrm{i}(\mathrm{i}=1, \ldots, 10)$; Cyc $\mathrm{c}_{\mathrm{k}}$ the fixed effect of Cycle $\mathrm{k}(\mathrm{k}=1, \ldots, 6) ;(\text { Cyc } \tau)_{\mathrm{ik}}$ the fixed interaction effect between Cycle and treatment; $\rho_{I}$ the fixed effect of block $I(I=1,2)$; and $e_{i k \mid}$ the random error of the ilth plot in cycle k.

When analyzing LTEs, temporal autocorrelation of plot residuals and possible variance heterogeneity caused by years has to be considered (Onofri et al. 2016; Payne 2015; Reckling et al. 2021, Richter and Kroschewski 2006). We fitted the following temporal correlation structures as candidate models (notation as in Richter and Kroschewski 2006): NC (no correlation - serves as basic model), CS (compound symmetry, constant temporal correlation for the observations in each plot), AR(1) (autoregressive approach, the correlation between observations in each plot depends on their temporal distance from each other, consecutive years correlate most strongly, with larger distance the correlation decreases according to an exponential function), combined with the assumption of homogeneous cycles variances. Further, we combined the correlation structures with the assumption of heterogeneous cycles variances (notation: $\mathrm{NCH}, \mathrm{CSH}, \mathrm{ARH}(1)$ ). The model fit was evaluated by the Corrected Akaike's information criteria (AICC). Differences between Least Square Means (LS-Means) were compared with the least significant difference (LSD) as critical difference at $\alpha=0.05$.

The trend function describing the time course of SOC values was estimated using the following model, separately for each rotation:

$$
y_{i k l}=\mu+\tau_{i}+b_{i} \cdot \exp \left(-C y c_{k}\right)+\rho_{l}+e_{i k l}
$$

where $\mathrm{y}_{\mathrm{ikl}}$ is the observed value for $\mathrm{i}$ th straw treatment, $\mathrm{k}$ th cycle and Ith block; $\mu$ the population mean; $\tau_{\mathrm{i}}$ the fixed effect of straw treatment $i(i=1, \ldots, 4) ; b_{i}$ the fixed regression coefficient per straw treatment $i$ $(i=1, \ldots, 4) ; \rho_{I}$ the fixed effect of block $I(I=1,2)$; and $e_{i k l}$ the random error of the ilth plot in cycle $k$.

The cycles were coded as 1...6. The SOC values averaged per plot for 1975 (year before study period started) and 1976 were used as initial situation at cycle $=0.5$. For the treatments, heterogeneous variances were considered. A specific coefficient a in the exponent as well as fitting covariance structure for plot values did not result in better model fit.

For all models, we assumed normally distributed random residuals with zero expectation. 
Statistical analysis (MIXED procedure using REML method, Stroup et al. 2018) and graphical presentations were performed using SAS 9.4 software (SAS Institute Inc., Cary, NC, USA). For the assessment of statistical tests, calculation of confidence intervals and critical differences, alpha $=0.05$ was used.

\section{Results}

\section{Spring barley - grain and straw yield}

Grain and straw yield were evaluated by fitting model (1) per rotation over all 6 cycles. Detailed information on model fit, covariance parameters, and test results for the best fitted model can be found in the supplemental material (Table S1, S2). For grain yield, there was a strong main effect of cycle (rotation 1-3: $P<0.001$ ), and an interaction effect between $N$ fertilization and cycle (rotation 1,2: $P<0.001$, rotation 3 : $\mathrm{P}=0.003$ ). The absence of a main effect of $\mathrm{N}$ suggests that $\mathrm{N}$ affected grain yield differently in different years and had to be partially counteracting. In contrast to grain yield, significant main effects were found for straw yield for both cycle (rotation 1-3: $\mathrm{P}<0.001$ ) and $\mathrm{N}$ (rotation 1-3: $\mathrm{P}<0.001$ ). However, $\mathrm{N}$ also affected straw yield differently among years (cycle $x \mathrm{~N}$ effect for rotation 1 : $\mathrm{P}=0.006$, rotation 2 : $P=0.036$, rotation 3: $P=0.045)$. Straw application had no effect on either trait (except straw yield, rotation 1, $\mathrm{P}=0.049$ for main straw effect), however, barley is grown 2 years after the last straw application.

Since straw application had no effect on barley grain and straw yields, pairwise comparisons of $\mathrm{N}$ levels averaged over straw levels are presented (pairwise comparisons as mean impression averaged over all barley years in Fig. 3, comparisons in individual years in Fig. S1, S2). The graphs show the treatment LSMeans with half the critical difference LSD for $a=0.05$ as error bars. If the error bars of two mean values do not overlap, a difference between these two treatment means is indicated.

Grain yield of barley was strongly dependent on precipitation. In years with rather above-average precipitation, yields tended to improve with the increase from $40 \mathrm{~kg} \mathrm{~N} \mathrm{ha}^{-1}$ to higher $\mathrm{N}$ amounts (1977, 1981, 1993), while in years with below-average precipitation (1985 and especially 1989 with extremely low precipitation in early summer and high temperatures, Fig. 2) the opposite was the case: more than 40 $\mathrm{kg} \mathrm{ha}^{-1} \mathrm{yr}^{-1} \mathrm{~N}$ led to the same or lower grain yield. Rotation 3 with 100\% cereals had the lowest yield level, and there were almost consistently no or negative $\mathrm{N}$ effects (Fig. S1). On average, more than $40 \mathrm{~kg} \mathrm{~N} \mathrm{ha-1}$ did not result in any barley grain yield gain (Fig. 3), except for the increase from 40 to $160 \mathrm{~kg} \mathrm{~N} \mathrm{ha}^{-1} \mathrm{yr}^{-1}$ in rotation 2 .

$\mathrm{N}$ amounts affected straw yield more than grain yield, particularly in the two crop rotations with $50 \%$ or $75 \%$ cereals, respectively (Fig. 3). These rotations almost consistently showed higher straw yields in each year with increasing amounts of $\mathrm{N}$ from $40 \mathrm{~kg} \mathrm{ha}^{-1} \mathrm{yr}^{-1}$ upward, while rotation 3 showed no $\mathrm{N}$ effect in 4 of 6 years (Fig. S2).

\section{Winter rye - grain and straw yield}


Grain and straw yield were analyzed per rotation over all 6 cycles (model 1), detailed information on model fit, covariance parameters, and test results for the best fitted model are given in the supplemental material (Table S3, S4).

For grain yield, we identified a strong main effect of cycles (rotation 1-3: $P<0.001), N$ (rotation 1,2: $P<0.001$, rotation 3: $P=0.004$ ), and their interaction effect (rotation 1: $P=0.020$, rotation 2,3: $P<0.001$ ). As for spring barley, straw application had no effect on grain yield, even though spring barley is the preceding crop and the "straw return" treatment supplies barley straw to winter rye.

For straw yield, a strong main effect of cycle (rotation 1-3: $\mathrm{P}<0.001), \mathrm{N}$ (rotation 1-3: $\mathrm{P}<0.001$ ), and their interaction effect - only for rotation 2 and 3 - were found (rotation 1: $P=0.103$, rotation 2,3: $P<0.001$ ).

In rotation 1, no effect of straw application was detected; in rotations 2 and 3 , this effect was yeardependent (interaction effect cycle $x$ straw in rotation 2 : $P<0.001$, rotation $3: P=0.004$ ), but this effect vanished for all rotations on average over the 6 cycles (no main effect).

Again, since straw application had no or little effect on rye grain and straw yields, pairwise comparisons of $\mathrm{N}$ levels averaged over straw levels are presented (as mean impression averaged over all rye years in Fig. 4, comparisons in individual years in Supplemental Fig. S3, S4).

The magnitude of grain and straw yields as well as their differentiation by $\mathrm{N}$ levels varied greatly between years. Since in all rye years the precipitation totals were at least average for both vegetation and early summer, the precipitation tends not to be an issue (Fig. 2). Unlike barley, increasing the $\mathrm{N}$ amount from 40 to $80 \mathrm{~kg} \mathrm{ha}^{-1} \mathrm{yr}^{-1}$ resulted in higher grain yield on average over the cycles, and also from 80 to $120 \mathrm{~kg} \mathrm{ha}^{-1}$

$\mathrm{yr}^{-1}$ in rotation 2. A further increase in the amount of $\mathrm{N}$ did not bring any benefit. As with barley, $\mathrm{N}$ affected straw yield more strongly. For all rotations and all cycles, increasing $\mathrm{N}$ from $40 \mathrm{~kg} \mathrm{ha}^{-1} \mathrm{yr}^{-1}$ to a higher $\mathrm{N}$ level resulted in higher straw yields, and partially the yield even increased up to the highest $\mathrm{N}$ level of 160 $\mathrm{kg} \mathrm{ha}^{-1} \mathrm{yr}^{-1}$.

\section{Straw amount returned from test crops}

In the straw application treatment S11, the harvested straw amount was returned from both test crops. Table 2 shows the straw quantity per cycle for this treatment as the sum of LS-Means in straw yield of both test crops estimated by model (1) depending on the mineral $\mathrm{N}$ level. Averaged over the 6 cycles, in rotation $1 \mathrm{~N} 4$ produced 1.5 times the amount of straw of $\mathrm{N} 1$, in rotation 2 the factor is 1.4 , and in rotation 3 about 1.2 .

\section{Soil organic carbon content}

Unlike the majority of LTEs, annual plot values for SOC in the topsoil are available for our trial. The development of annual treatment means over time is shown in Figure 5. Crop rotation 1 with 50\% cereals showed the strongest decline in SOC values, crop rotation 2 showed a less pronounced decline, while SOC values in crop rotation 3 with $100 \%$ cereals remained at about the same level. 
The treatments receiving straw from test crops had almost consistently higher SOC values than the treatments without straw return. The influence of $\mathrm{N}$ fertilization appeared to be less pronounced. For all rotations, the treatment without organic manure since 1937 had the lowest initial SOC value at the beginning of the study period, but became closer to the other treatments without straw return over time.

The four consecutive years of a treatment belonging to a cycle differed both in crops and in the straw application (only in two of the four years), which might have influenced SOC values differently. Therefore, plot values averaged across the years per cycle were used for the following analysis.

Using the 2 straw $x 4$ nitrogen treatments, the effects of organic manure, mineral $\mathrm{N}$ fertilization, and their interaction on SOC were evaluated by fitting model (1) per rotation over all 6 cycles. Detailed information on model fit, covariance parameters, and test results for the best fitted model can be found in the supplemental material (Table S5).

In all rotations there was a main effect of straw application on $S O C$ values (rotation $1: P=0.021$, rotation 2: $P=0.016$, rotation 3: $P=0.009$ ), a main effect of cycle (rotation 1-3: $P<0.001$ ) and, except rotation 1 , also an interaction effect between straw application and cycle (rotation 1: $P=0.189$, rotation 2: $P=0.003$, rotation 3: $P=0.006$ ). In contrast, there was no effect of tested mineral $N$ rates on $S O C$, neither as a main effect nor as an interaction effect with straw application or cycle.

Since $\mathrm{N}$ had no effect on SOC, but the treatment without any organic manure since 1937 showed a different trend in SOC values (Fig. 5), another model (2) was fitted for the joint analysis of all 10 treatments (see supplemental Table S5 for details). Only the pairwise comparisons of the 4 straw treatments at the same $\mathrm{N}$ level ( $\mathrm{N} 3=120 \mathrm{~kg} \mathrm{~N} \mathrm{ha}^{-1} \mathrm{yr}^{-1}$ ) were chosen to present the results (Fig. 6). In the first cycle, there was a clear mean difference between the treatment S00\# without any organic manure since 1937 and the other treatments in all crop rotations. The differentiation changed in the following cycles, the treatments without organic manure since 1976 became closer in the mean, while treatment S11 with continued organic manure became increasingly different from the others.

Describing the long-term trend of SOC values is often more interesting. With model (3) exponential functions were fitted to estimate SOC trend functions for the four straw treatments (Fig. 7). The LS-Mean values estimated using the exponential functions show the average trend of the SOC values over the study period (6 cycles). The fit of the estimated functions to the observed plot values varied, but the general behavior of SOC values in time, already roughly described in Fig. 5, can be better derived.

Initial SOC values for 1976 ranged from 6.5 to $7.2 \mathrm{~g} \mathrm{~kg}^{-1}$ soil for both treatments S10 and S11, which were supplied with FYM until 1971. Although also supplied with FYM, the initial value for S10\# was slightly lower because this treatment received no potassium until 1971. Treatment S00\# without any organic manure since 1937 always had the smallest initial values (4.3 to 5.2). Until 1971, treatments were tested in rotations with $50 \%$ cereals, so different crop rotations did not yet play a role. During the study period, the treatment S11 with straw return of the test crops consistently showed the highest SOC values and differed increasingly from the other treatments without organic manure. The latter approached each 
other on the same level, and the respective change (increase, decrease, stagnation) depended on the SOC initial value. Trend functions of S00\# in rotation 1 and 2 as well as S10\# in rotation 3 stagnated, these treatments obviously behaved in equilibrium. The rotations showed marked differences in SOC levels and

in the magnitude of change in $\mathrm{SOC}$ values, obviously there is a negative influence of the non-cereal crops on SOC.

After 6 cycles, relatively stable SOC values can be observed. The comparison of SOC mean values shows that the S11 treatment was superior to all other treatments on average, partially there were also differences between other treatments, especially to S00\# with the lowest mean value.

Besides SOC content, the most interesting aspect is the extent of carbon sequestration in the soil and its change due to the different treatments in the three rotations during the study period. Based on the SOC contents estimated by the exponential functions (Fig. 7) at the beginning (cycle $=0.5$ as initial situation in 1975/76) and at the end of the study period (cycle=6 with the years 1996-1999 as final situation), the SOC stocks ( $\mathrm{Mg} \mathrm{ha}^{-1}$ ) in the 0 - to 20 -cm layer were derived (Table 3 ). The differentiation of carbon stock values between the straw application treatments as well as their change in time is analogous to SOC content values (Fig. 7).

The magnitude of stored carbon for S00\# was always below $18 \mathrm{Mg} \mathrm{ha}^{-1}$ (stagnated in rotations 1 and 2 with values around 13 and $16 \mathrm{Mg} \mathrm{ha}^{-1}$, increased from 15 to $18 \mathrm{Mg} \mathrm{ha}^{-1}$ in rotation 3). For the other treatments, the quantities were between 19 and $22 \mathrm{Mg} \mathrm{ha}^{-1}$ at the beginning, decreased to values between 14 and $17 \mathrm{Mg} \mathrm{ha}^{-1}$ in rotation 1, to values between 17 and $19 \mathrm{Mg} \mathrm{ha}^{-1}$ in rotation 2, and stagnated at the same value or changed only slightly in rotation 3 . Treatment S11 had the highest stored carbon quantities at the end of the experimental period.

\section{Discussion}

\section{Crop rotation}

Our results clearly indicate that more cereals in the crop rotation resulted in higher SOC contents. These differences between the crop rotations can be attributed to the different amounts of organic inputs to the soil and the intensity of tillage operations related to the management of the test crops. The sugar beet in particular which is cultivated in the $50 \%$ and $75 \%$ cereal rotations is known for a comparatively small mass of belowground residues (Bolinder et al. 2015; Koga et al. 2011). In addition, sugar beet leaves have a comparatively low $\mathrm{C}: \mathrm{N}$ ratio (Bending et al. 2002). Hence, they are decomposed more rapidly than cereal residues and provide less reproduction of SOC. Moreover, mechanical weed control and physical disturbance of soil during harvest of sugar beet can initiate mineralization processes and therefore contribute to the decomposition of organic matter.

Silage maize was cultivated in the $50 \%$ cereal rotation only. The relative contribution of maize residues to SOC is lower than wheat residues (Liu et al. 2020). Recently, Grunwald et al. (2021) found SOC stocks in a 
12-year field experiment to be significantly higher in a sugar beet - wheat - wheat rotation than in a sugar beet - wheat - silage maize rotation. These authors reported that aboveground residues of the test crops were different in the order of wheat > sugar beet > silage maize. Hence it is plausible that the rotation had a pronounced effect on the SOC contents in our experiment. When row crops such as sugar beet or silage maize are cultivated, particular care for conserving SOC should be taken. For instance, direct drilling and mulching have reported to be adequate means for soil protection in sugar beet cultivation (Jacobs et al. 2015). However, it should be noted that changes in SOC contents depend on the initial values. In the treatment with a very low initial SOC content, even the $50 \%$ cereal rotation did not result in a further decline of SOC.

\section{Straw application}

In the last cycle of our study period (Fig. 6), straw return (treatment S11) increased SOC content by 12 to $15 \%$ over the treatment with straw removal (treatment S10). Hence, the effect of straw return on SOC was much smaller than the effect of the rotation. In the literature, similar effect sizes of straw application have been reported: Liu et al. (2003) have found SOC of a black soil to be increased by $14.5 \%$ due to straw application in a wheat - soybean rotation. Likewise, Luxhøi et al. (2007) have shown straw application to increase organic $\mathrm{N}$ of a light sandy loam by $16-17 \%$. In a long-term field experiment on a sandy loam, straw application increased SOC by 13\% (Kismányoky and Tóth 2010). Poeplau (2015), on the other hand, found little or no positive effect of incorporating straw residues on SOC stocks in most of the six Swedish LTEs studied.

However, even moderate SOC changes contribute to carbon sequestration in soils and can have positive effects of soil biological activity (Kautz et al. 2004) and soil physical properties (Abiven et al. 2007). Thus, our results highlight the importance of straw application for maintaining soil fertility, in particular in rotations with a low potential for reproduction of organic matter.

In contrast, grain yield was not influenced by straw application. This is in line with results of a metaanalysis comparing straw return with standard controls (Chen et al. 2018), though single investigation has shown a yield promoting effect of straw application (Kismányoky and Tóth 2013). From Broadbalk Wheat Experiment, Macholdt et al. (2020) found also no effect between straw removal and straw return on yield in the continuous wheat rotation for mineral fertilized treatments. Generally, yield effects of cereal straw are limited by its high potential for the immobilization of nitrogen (Grzyb et al. 2020). In our field trial, straw was applied without additional nitrogen to balance the $\mathrm{C}: \mathrm{N}$ ratio. It has been suggested that straw application would improve soil water conservation therefore promoting crop yields particularly under dry conditions (Singh et al. 1998), however despite our LTE is located in a relatively dry area, this effect was not observed.

\section{$\mathrm{N}$ fertilization}

Rye grain yield was significantly influenced by mineral $\mathrm{N}$ fertilization which has been previously reported for soils of the study area (Benkenstein et al. 1994; Eulenstein et al. 2011). In contrast, grain yield of spring barley remained unaffected by $\mathrm{N}$ rates tested in our LTE. Spring barley has generally lower nitrogen 
requirements than winter rye, mainly because yield and $\mathrm{N}$ uptake are much lower. At our site of investigation, spring cereals generally exhibit comparatively low yields because of frequent dry spells during early plant development. As stated by Anbessa et al. (2009), the average nitrogen use efficiency of spring barley is $42 \mathrm{~kg} \mathrm{ha}^{-1} \mathrm{yr}^{-1} \mathrm{~N}$. In the dry years of our experiment, grain yield of barley was generally below $3 \mathrm{Mg} \mathrm{ha}^{-1}$ which translates to a total $\mathrm{N}$ demand of less than $71 \mathrm{~kg} \mathrm{~N} \mathrm{ha}^{-1} \mathrm{yr}^{-1}$. Given that some plant available nitrogen was present in the soil solution it is plausible that fertilization of $80 \mathrm{~kg} \mathrm{~N} \mathrm{ha}^{-1} \mathrm{yr}^{-1}$ already exceeded the requirements of spring barley and did not affect grain yield.

Straw yield of both cereals was increased by mineral $\mathrm{N}$ fertilization. Thus, the total amount of straw returned in the sum of all 6 cycles (study period) varied much more between $\mathrm{N}$ levels than between rotations. Although N4 produced up to 1.5 times more straw yield than N1, the differences in straw amounts caused by $\mathrm{N}$ fertilization did not affect SOC. In addition, higher aboveground biomass of cereals corresponds to higher amount of crop and root residues (Körschens 2021), hence the total amount of organic matter returned to the soil was increased by $\mathrm{N}$ rates. However, for SOC content, it only mattered in our LTE whether straw was returned from the test crops at all, but not the amount of organic matter.

As known from other field trials on infertile soils, the SOC sequestration efficiency of the organic amendments decrease under high application rates (Xu et al. 2022). Hence, we cannot expect a linear increase of SOC with an increase of straw input. Moreover, it has to be considered, that high mineral fertilization rates do not only increase straw return but also the concentration of soluble nitrogen in the soil solution, which increases the decomposition rates and thwarts a potential positive effect of SOC. High levels of mineral nitrogen mineralization ( 80 or $120 \mathrm{~kg} \mathrm{~N} \mathrm{ha}^{-1} \mathrm{yr}^{-1}$ ) did generally not increase crop

yield or soil organic matter. Hence the additional nitrogen most likely vanished from the system in form of leaching or gaseous losses. In some treatments, we have even recorded a decrease of SOC with an increase of nitrogen fertilization rate from N3 to N4 (e.g. 75\% cereal rotation, with straw return). This is in line with previous reports that mineral $\mathrm{N}$ fertilization can result in a net loss of native SOC and the residue carbon inputs (Khan et al. 2007).

\section{Temporal SOC change and SOC sequestration}

The temporal behavior of yearly SOC values (Fig. 5) was probably enhanced or superimposed by changes in temperature and precipitation during the vegetation period. Higher annual mean temperatures lead to a higher mineralization and thus degradation of the carbon stocks. However, modeled data (Fig. 7) from our LTE suggests that the annual input of organic carbon in organic material and decomposition processes of added and existing organic material balanced out after 24 years ( 6 cycles) for most treatments.

From a different LTE at Thyrow site, an inert SOC value of $3.2 \mathrm{~g} \mathrm{~kg}^{-1}$ (treatment without any fertilization for 70 years) could be derived, and for long-term "organic + mineral fertilized" treatments at high level SOC values of about $7 \ldots .8 \mathrm{~g} \mathrm{~kg}^{-1}$ were observed (Körschens et al. 2014, Körschens 2021). From this it would follow that the SOC values that can be influenced by management measures should be between 
3.2 and about $8 \mathrm{~g} \mathrm{~kg}^{-1}$ at this site. In fact, the SOC values of the LTE under study moved in this range. In the treatment with combined organic and mineral fertilization in the $100 \%$ cereal rotation, SOC moved to higher values of about $7.3 \mathrm{~g} \mathrm{~kg}^{-1}$, while in treatments with larger proportions of non-cereals in the rotation and/or without organic manure, SOC stagnated or tended toward lower values.

The German soil inventory identified average SOC stock values of $20.7 \pm 8.5 \mathrm{Mg} \mathrm{ha}^{-1}$ and $40.5 \pm 17.7 \mathrm{Mg}$ $\mathrm{ha}^{-1}$ in 0-10 and 10-30 cm depths for croplands on mineral soils respectively (Peoplau et al. 2020). We found values of around $20 \mathrm{Mg} \mathrm{ha}^{-1}$ or less in 0-20 cm sampling depth. This clearly indicates that the sandy soil under study contains a comparatively small carbon pool. However, depending on initial value and treatment, the observed magnitudes of changes in SOC stock over the 6 cycles were not negligible.

Until the start of the study period, all treatments - except S00\# - were tested with FYM and only in rotations with $50 \%$ cereals. Replacing FYM with straw application reduced SOC stocks by about $5 \mathrm{Mg}$ $\mathrm{ha}^{-1}$ in the rotation of an unchanged proportion of $50 \%$ cereals, and by about $4 \mathrm{Mg} \mathrm{ha}^{-1}$ in the rotation with $75 \%$ cereals, but not in the rotation with $100 \%$ cereals with almost unchanged or slightly rising SOC stocks. In contrast, the treatment without any organic manure since 1937 had the lowest initial levels. With continued non-supply, SOC stock stagnated in rotations with non-cereals and increased merely by removing all non-cereal crops from the rotation by about $3 \mathrm{Mg} \mathrm{ha}^{-1}$.

West and Post (2002) derived from long-term trials at 67 global sites, that a change from conventional to no-till can sequester an average $57 \pm 14 \mathrm{~g} \mathrm{C} \mathrm{m}^{-2} \mathrm{yr}^{-1}$, whereas enhancing rotation complexity can sequester an average $20 \pm 12 \mathrm{~g} \mathrm{C} \mathrm{m}^{-2} \mathrm{yr}^{-1}$. Börjesson et al. (2018) reported a change in SOC stocks after 35 years ranging between -0.36 and $+0.35 \mathrm{Mg} \mathrm{yr}^{-1}$ in topsoil $(0-20 \mathrm{~cm})$ from two LTEs in southern Sweden. Negative values were from cereal monocultures, and positive values were from ley rotations.

Our results of up to $5 \mathrm{Mg} \mathrm{ha}^{-1}$ SOC stock change correspond for a 24-year term to values up to $20.8 \mathrm{~g} \mathrm{C}$ $\mathrm{m}^{-2} \mathrm{yr}^{-1}$. Despite the overall carbon stocks are comparatively low, the results indicate that crop rotation and straw management have a significant impact on SOC and are relevant measures to sequester carbon.

\section{Abbreviations}

$\mathrm{BD}$ - bulk density

C - carbon

DM - dry matter

FYM - farm yard manure

LSD - least significant difference 
LS-Mean - least square mean

LTE - long-term experiment

$\mathrm{N}$ - nitrogen

SOC - soil organic carbon

\section{Declarations}

\section{Acknowledgements}

The authors thank current and former farm and laboratory staff for conducting the experiment and carrying out the analyses.

\section{CRediT authorship contribution statement}

Conceptualization: Kroschewski B; Investigation: Baumecker M; Data curation: Baumecker M, Methodology: Kroschewski B, Richter C; Formal analysis: Kroschewski B, Richter C; Visualization: Kroschewski B; Writing - original draft preparation: Kroschewski B; Writing - review and editing: Kautz T, Kroschewski B, Richter C.

All authors read and approved the final manuscript.

\section{Declarations}

The authors have no relevant financial or non-financial interests to disclose.

\section{References}

1. Abiven S, Menasseri S, Angers DA, Leterme P (2007) Dynamics of aggregate stability and biological binding agents during decomposition of organic materials. European Journal of Soil Science, 58 : 239-247. https://doi.org/10.1111/j.1365-2389.2006.00833.x

2. Anbessa Y, Juskiw P, Good A, Nyachiro J, Helm J, 2009. Genetic variability in nitrogen use efficiency of spring barley. Crop Science 49: 1259-1269. http://dx.doi.org/10.2135/cropsci2008.09.0566

3. Bending GD, Turner MK, Jones JE (2002) Interactions between crop residue and soil organic matter quality and the functional diversity of soil microbial communities. Soil Biology and Biochemistry 34 : 1073-1082. https://doi.org/10.1016/S0038-0717(02)00040-8.

4. Benkenstein $\mathrm{H}$, Pagel $\mathrm{H}$, Krüger W (1994) Einfluss unterschiedlicher $\mathrm{C}_{\mathrm{t}}$-gehalte von Böden des thyrower bodenfruchtbarkeitsversuches auf Ertrag sowie boden- und düngerstickstoffaufnahme im gefässversuch. Archives of Agronomy and Soil Science 38: 225-233.

https://doi.org/10.1080/03650349409365854 
5. Bolinder MA, Kätterer T, Poeplau C, Börjesson G, Parent LE (2015) Net primary productivity and below-ground crop residue inputs for root crops: Potato (Solanum tuberosum L.) and sugar beet (Beta vulgaris L.). Canadian Journal of Soil Science 95: 87-93. http://dx.doi.org/10.4141/CJSS-2014091

6. Börjesson G, Bolinder MA, Kirchmann H, Kätterer T (2018) Organic carbon stocks in topsoil and subsoil in long-term ley and cereal monoculture rotations. Biol Fertil Soils 54: 549-558. https://doi.org/10.1007/s00374-018-1281-x

7. Chen Y, Camps-Arbestain M, Shen Q, Singh B, Cayuela ML (2018) The long-term role of organic amendments in building soil nutrient fertility: a meta-analysis and review. Nutrient Cycling in Agroecosystems 111: 103-125. https://link.springer.com/article/10.1007/s10705-017-9903-5

8. Eulenstein F, Roth R, Tauschke M, Lana MA, Werner A (2011): Überprüfung von Düngungsstrategien zur Optimierung der Stickstoffdüngung für Weizen und Roggen zur Produktion von Ethanol durch dreijährige Feldversuche. In: Böden verstehen - Böden nutzen - Böden fit machen: DBGJahrestagung, 03.-09.09.2011, Berlin

9. Grunwald D, Götze P, Koch HJ (2021). Soil organic carbon stocks in sugar beet rotations differing in residue management and associated rotational crop species. Journal of Plant Nutrition and Soil Science, 184: 556- 561. https://doi.org/10.1002/jpln.202100122

10. Grzyb A, Wolna-Maruwka A, Niewiadomska A. (2020) Environmental Factors Affecting the Mineralization of Crop Residues. Agronomy. 10(12):1951.

https://doi.org/10.3390/agronomy 10121951

11. IUSS Working Group WRB (2015) World Reference Base for Soil Resources 2014, update 2015. International soil classification system for naming soils and creating legends for soil maps. World Soil Resources Reports No. 106. FAO, Rome.

12. Jacobs A, Jungert $S$, Koch H-J (2015) Soil organic carbon as affected by direct drilling and mulching in sugar beet - wheat rotations, Archives of Agronomy and Soil Science, 61(8): 1079-1087. https://doi.org/10.1080/03650340.2014.981669

13. Johnston AE, Poulton PR, Coleman K, Macdonald AJ, White RP (2017) Changes in soil organic matter over 70 years in continuous arable and ley-arable rotations on a sandy loam soil in England. Eur J Soil Sci, 68: 305-316. https://doi.org/10.1111/ejss.12415

14. Kaiser M, Ellerbrock R, Gerke H (2007) Long-term effects of crop rotation and fertilization on soil organic matter composition. European Journal of Soil Science 58: 1460-1470.

15. Kautz T, Wirth S, Ellmer F (2004) Microbial activity in a sandy arable soil is governed by the fertilization regime. European journal of soil biology 40: 87-94. https://doi.org/10.1016/j.ejsobi.2004.10.001

16. Khan SA, Mulvaney RL, Ellsworth TR, Boast CW (2007) The myth of nitrogen fertilization for soil carbon sequestration. J Environ Qual. 36(6):1821-1832. https://doi.org/10.2134/jeq2007.0099

17. Kismányoky T, Tóth Z (2010) Effect of mineral and organic fertilization on soil fertility as well as on the biomass production and $\mathrm{N}$ utilization of winter wheat (Triticum aestivum L.) in a long-term cereal 
crop rotation experiment (IOSDV). Archives of Agronomy and Soil Science 56: 473-479. https://doi.org/10.1080/03650340903296819

18. Kismányoky T, Tóth Z (2013) Effect of mineral and organic fertilization on soil organic carbon content as well as on grain production of cereals in the IOSDV (ILTE) long-term field experiment, Keszthely, Hungary. Archives of Agronomy and Soil Science 59: 1121-1131. https://doi.org/10.1080/03650340.2012.712208

19. Koga N, Smith P, Yeluripati JB, Shirato Y, Kimura SD, Nemoto M (2011) Estimating net primary production and annual plant carbon inputs, and modelling future changes in soil carbon stocks in arable farmlands of northern Japan. Agriculture, Ecosystems \& Environment 144: 51-60. http://dx.doi.org/10.1016/j.agee.2011.07.019

20. Körschens M, Albert E, Baumecker M, Ellmer F, Grunert M, Hoffmann S, Kismanyoky T, Kubat J, Kunzova E, Marx M, Rogasik J, Rinklebe J, Rühlmann J, Schilli C, Schröter H, Schroetter S, Schweitzer K, Toth Z, Zimmer J, Zorn W (2014) Humus and climate change - results of 15 long-term experiments, Archives of Agronomy and Soil Science 60 (11): 1485-1517.

https://doi.org/10.1080/03650340.2014.892204

21. Körschens M (2021) Long-Term Field Experiments (LTEs) - Importance, Overview, Soil Organic Matter. In: Mueller L, Sychev VG, Dronin NM, Eulenstein F (editors) Exploring and optimizing agricultural landscapes. Innovations in landscape research. Springer Nature Switzerland AG, Chapter 8: pp 215231. https://doi.org/10.1007/978-3-030-67448-9

22. Liu X, Han X, Song C, Herbert S, Xing B (2003) Soil organic carbon dynamics in black soils of China under different agricultural management systems. Communications in Soil Science and Plant Analysis 34. 973-984. http://dx.doi.org/10.1081/CSS-120019103

23. Liu Z, Gao T, Tian S, Hu H, Li G, Ning T (2020) Soil organic carbon increment sources and crop yields under long-term conservation tillage practices in wheat-maize systems. Land Degradation \& Development 31: 1138-1150. https://doi.org/10.1002/ldr.3531

24. Luxhøi J, Elsgaard L, Thomsen I, Jensen L (2007) Effects of long-term annual inputs of straw and organic manure on plant $\mathrm{N}$ uptake and soil $\mathrm{N}$ fluxes. Soil use and management 23: 368-373. http://dx.doi.org/10.1111/j.1475-2743.2007.00126.x

25. Macholdt J, Piepho H-P, Honermeier B, Perryman S, Macdonald A, Poulton P (2020) The effects of cropping sequence, fertilization and straw management on the yield stability of winter wheat (19862017) in the Broadbalk Wheat Experiment, Rothamsted, UK. J. Agric. Sci. 158: 65-79. https://doi.org/10.1016/j.fcr.2021.108083

26. Onofri A, Seddaiu G, Piepho H-P (2016) Long-term experiments with cropping systems: case studies on data analysis. Eur J Agron 77: 223-235. https://doi.org/10.1016/j.eja.2016.02.005

27. Payne RW (2015) The design and analysis of long-term rotation experiments. Agron J 107 (2): $772-$ 785. https://doi.org/10.2134/agronj2012.0411

28. Poeplau C, Kätterer T, Bolinder MA, Börjesson G, Berti A, Lugato E (2015) Low stabilization of aboveground crop residue carbon in sandy soils of Swedish long-term experiments. Geoderma 237- 
238: 246-255. https://doi.org/10.1016/j.geoderma.2014.09.010.

29. Poeplau C, Jacobs A, Don A, Vos C, Schneider F, Wittnebel M, Tiemeyer B, Heidkamp A, Prietz R, Flessa $H$ (2020) Stocks of organic carbon in German agricultural soils - Key results of the first comprehensive inventory. J. Plant Nutr. Soil Sci., 183: 665-681.

https://doi.org/10.1002/jpln.202000113

30. Poulton P, Johnston J, Macdonald A, White R, Powlson D. (2018) Major limitations to achieving "4 per 1000" increases in soil organic carbon stock in temperate regions: Evidence from long-term experiments at Rothamsted Research, United Kingdom. Glob Change Biol. 24: 2563- 2584. https://doi.org/10.1111/gcb.14066

31. Rasmussen PE, Goulding KWT, Brown JR, Grace PR, Janzen HH, Körschens M (1998). Long-term agroecosystem experiments: assessing agricultural sustainability and global change. Science. 282 (5390): 893-896. https://doi.org/10.1126/science.282.5390.893

32. Reckling M, Ahrends H, Chen TW, Eugster W, Hadasch S, Knapp S, Laidig F, Linstädter A, Macholdt J, Piepho H-P, Schiffers K, Döring, TF (2021) Methods of yield stability analysis in long-term field experiments. A review. Agron. Sustain. Dev. 41, 27. https://doi.org/10.1007/s13593-021-00681-4

33. Richter C, Kroschewski B (2006) Analysis of a long-term experiment with repeated-measurement models. J Agron Crop Sci 192 (1): 55-71. https://doi.org/10.1111/j.1439-037X.2006.00167.x

34. Singh B, Chanasyk D, McGill W (1998) Soil water regime under barley with long-term tillage-residue systems. Soil and Tillage Research 45: 59-74. https://doi.org/10.1016/S0167-1987(97)00067-6

35. Springer U, Klee J (1955) Feststellung der optimalen Reaktionsverhältnisse beim reduktometrischen Chromschwefelsäureverfahren zur Schnellbestimmung von Kohlenstoff und Vorschlag einer verbesserten Arbeitsweise. Zeitschrift für Pflanzenernährung, Düngung und Bodenkunde 71 (3):193208

36. Stroup WW, Milliken GA, Claassen EA (2018) SAS for Mixed Models: Introduction and Basic Applications. SAS Institute.

37. Stumpf B, Glendining M, Grosse M, Hoffmann C, Joschko M, König S, Kroschewski B, Cardoso Lisboa C, Macdonald A, Macholdt J, Makádi M, Ostler R, Perryman S. Piepho H-P, Schnell S, Storkey J, Vaziritabar Y, Weller U, Honermeier B (2021). Long-Term-Experiments - methods, standardization and modelling. BonaRes Series. https://doi.org/https://doi.org/10.20387/bonares-fzk2-tf22

38. West TO, Post WM (2002) Soil organic carbon sequestration rates by tillage and crop rotation. Soil Sci. Soc. Am. J., 66: 1930-1946. https://doi.org/10.2136/sssaj2002.1930

39. Xu C, Wang J, Wu D, Li C, Wang L, Ji C, Zhang Y, Ai Y (2022) Optimizing organic amendment applications to enhance carbon sequestration and economic benefits in an infertile sandy soil, Journal of Environmental Management (303) https://doi.org/10.1016/j.jenvman.2021.114129

40. Zhao Y, Wang P, Li J, Chen Y, Ying X, Liu S, (2009) The effects of two organic manures on soil properties and crop yields on a temperate calcareous soil under a wheat-maize cropping system. European Journal of Agronomy 31: 36-42. 
41. Zimmer J, Ellmer F, Kroschewski B (2014) Humusreproduktionsleistung von Stalldung im Dauerfeldversuch M4 Groß Kreutz. VDLUFA-Schriftenreihe 69: 89-96.

\section{Tables}

Table 1 Description of treatments $\S$ per rotation of LTE Thy_D5 during the experimental period 1976 1999 (6 cycles)

\begin{tabular}{|c|c|c|c|}
\hline Treatment factor & Level & Label & Description \\
\hline A: Straw application \& & 4 & So0\# & none (since 1937 no organic manure) \\
\hline (straw return from test crop, & 3 & S10\# & none (until 1971: FYM $15 \mathrm{Mg} \mathrm{ha}^{-1} \mathrm{yr}^{-1}$ ) \\
\hline $\begin{array}{l}\text { harvested amount, no } \\
\text { additional }\end{array}$ & 1 & S10 & none (until 1971: FYM $15 \mathrm{Mg} \mathrm{ha}^{-1} \mathrm{yr}^{-1}$ ) \\
\hline $\begin{array}{l}\text { nitrogen to balance the } C: N \\
\text { ratio) }\end{array}$ & 2 & S11 & with (until 1971: FYM $15 \mathrm{Mg} \mathrm{ha}^{-1} \mathrm{yr}^{-1}$ ) \\
\hline B: Mineral $\mathbf{N}$ fertilization & 1 & N1 & $40 \mathrm{~kg} \mathrm{ha}^{-1} \mathrm{yr}^{-1}$ (low) \\
\hline \multirow[t]{3}{*}{ (quantities applied to cereals) } & 2 & N2 & $\begin{array}{l}80 \mathrm{~kg} \mathrm{ha}^{-1} \mathrm{yr}^{-1} \text { (medium = best practice at the } \\
\text { site) }\end{array}$ \\
\hline & 3 & N3 & $120 \mathrm{~kg} \mathrm{ha}^{-1} \mathrm{yr}^{-1}$ (high) \\
\hline & 4 & N4 & $160 \mathrm{~kg} \mathrm{ha}^{-1} \mathrm{yr}^{-1}$ (very high) \\
\hline
\end{tabular}

§ all treatments received $48 \mathrm{P} \mathrm{kg} \mathrm{ha}^{-1} \mathrm{yr}^{-1}$ and $200 \mathrm{~kg} \mathrm{~K} \mathrm{ha}^{-1} \mathrm{yr}^{-1}$

\& first digit of label indicates the organic manure until 1971, second digit indicates the organic manure in the study period ( $0=$ none, $1=$ with).

\# special additional treatments without potassium fertilization during the time of the potassium trial until 1971 , combined with N3 only (all other treatments received 66 or $100 \mathrm{~kg} \mathrm{~K} \mathrm{ha}^{-1} \mathrm{yr}^{-1}$ during the time of potassium trial)

Table 2 Mean amount of straw $\left(\mathrm{Mg} \mathrm{ha}^{-1}\right)$ per cycle returned from both test crops to straw application treatment $\mathrm{S} 11$ (minimum and maximum amount per cycle in parentheses) 


\begin{tabular}{|llll|}
\hline Nitrogen level \& & Rotation $1(50 \%$ cereals $)$ & Rotation 2 $(75 \%$ cereals $)$ & Rotation 2 $(100 \%$ cereals $)$ \\
\hline N1 & $5.8(4.0 ; 8.2)$ & $5.8(3.6 ; 7.9)$ & $6.3(4.2 ; 8.3)$ \\
\hline N2 & $7.3(5.3 ; 9.9)$ & $7.4(4.8 ; 9.4)$ & $7.1(4.6 ; 9.1)$ \\
\hline N3 & $8.5(5.8 ; 11.3)$ & $8.1(5.3 ; 10.7)$ & $7.5(4.9 ; 10.2)$ \\
\hline N4 & $8.8(6.3 ; 12.6)$ & $8.3(5.7 ; 11.4)$ & $7.8(5.3 ; 11.3)$ \\
\hline
\end{tabular}

\& For detailed description of $\mathrm{N}$ levels, see Table 1.

Table 3 Soil organic carbon stocks ( $\mathrm{Mg} \mathrm{ha}^{-1}, 0-20 \mathrm{~cm}$ soil depth) of LTE Thy_D5 at the beginning and at the end of the experimental period 1976 - 1999. Calculation based on LS-Means and their confidence limits ( $P=0.95)$ for SOC from exponential functions (Fig. 5), dry bulk density was calculated by $B D=1.628 \cdot e^{-0.084 \cdot S O C}$

\begin{tabular}{|lcccccc|}
\hline Straw & \multicolumn{2}{c}{ Rotation $1(50 \%$ cereals $)$} & \multicolumn{2}{l}{ Rotation $2(75 \%$ cereals $)$} & \multicolumn{2}{l|}{ Rotation $2(100 \%$ cereals $)$} \\
\hline application $~$ & $1975 / 76$ & $1996-99$ & $1975 / 76$ & $1996-99$ & $1975 / 76$ & $1996-99$ \\
\hline S00\# & $13.4 \pm 0.7$ & $13.6 \pm 0.4$ & $16.2 \pm 0.9$ & $15.8 \pm 0.5$ & $15.4 \pm 1.3$ & $18.4 \pm 0.7$ \\
S10\# & $18.7 \pm 0.4$ & $14.3 \pm 0.2$ & $20.7 \pm 0.5$ & $16.9 \pm 0.3$ & $19.8 \pm 0.7$ & $19.8 \pm 0.4$ \\
S10 & $20.0 \pm 2.0$ & $15.0 \pm 1.2$ & $22.1 \pm 0.6$ & $17.7 \pm 0.3$ & $21.0 \pm 1.6$ & $19.7 \pm 0.9$ \\
S11 & $21.6 \pm 0.8$ & $17.3 \pm 0.5$ & $22.0 \pm 1.0$ & $19.3 \pm 0.5$ & $20.4 \pm 1.0$ & $21.6 \pm 0.5$ \\
\hline
\end{tabular}

\& Selected straw application treatments combined with $120 \mathrm{~kg} \mathrm{~N} \mathrm{ha}^{-1} \mathrm{yr}^{-1}$ only. For detailed description, see Table 1.

\section{Figures}




\begin{tabular}{|c|c|c|c|c|c|c|c|c|c|c|c|}
\hline Rotation & Block & & & & & & & & & & \\
\hline 3 & 2 & 22 & 24 & 11 & 13 & 33 & 43 & 23 & 21 & 14 & 12 \\
\hline (100\% cereals) & 1 & 33 & 43 & 14 & 12 & 23 & 21 & 22 & 24 & 11 & 13 \\
\hline 2 & 2 & 23 & 21 & 24 & 22 & 11 & 13 & 14 & 33 & 43 & 12 \\
\hline (75\% cereals) & 1 & 12 & 14 & 33 & 43 & 21 & 23 & 11 & 13 & 22 & 24 \\
\hline 1 & 2 & 22 & 21 & 11 & 12 & 23 & 24 & 33 & 43 & 13 & 14 \\
\hline (50\% cereals) & 1 & 14 & 13 & 24 & 23 & 12 & 11 & 22 & 21 & 33 & 43 \\
\hline
\end{tabular}

Figure 1

Layout of LTE Thy_D5 with 2 replications, plot size $6 \mathrm{~m}$ x $8 \mathrm{~m}$, experimental area $60 \mathrm{~m}$ x $48 \mathrm{~m}$, within plots treatment levels for both factors: first digit = straw application, second digit $=$ mineral $\mathrm{N}$ fertilization (see Table 1 for further details).

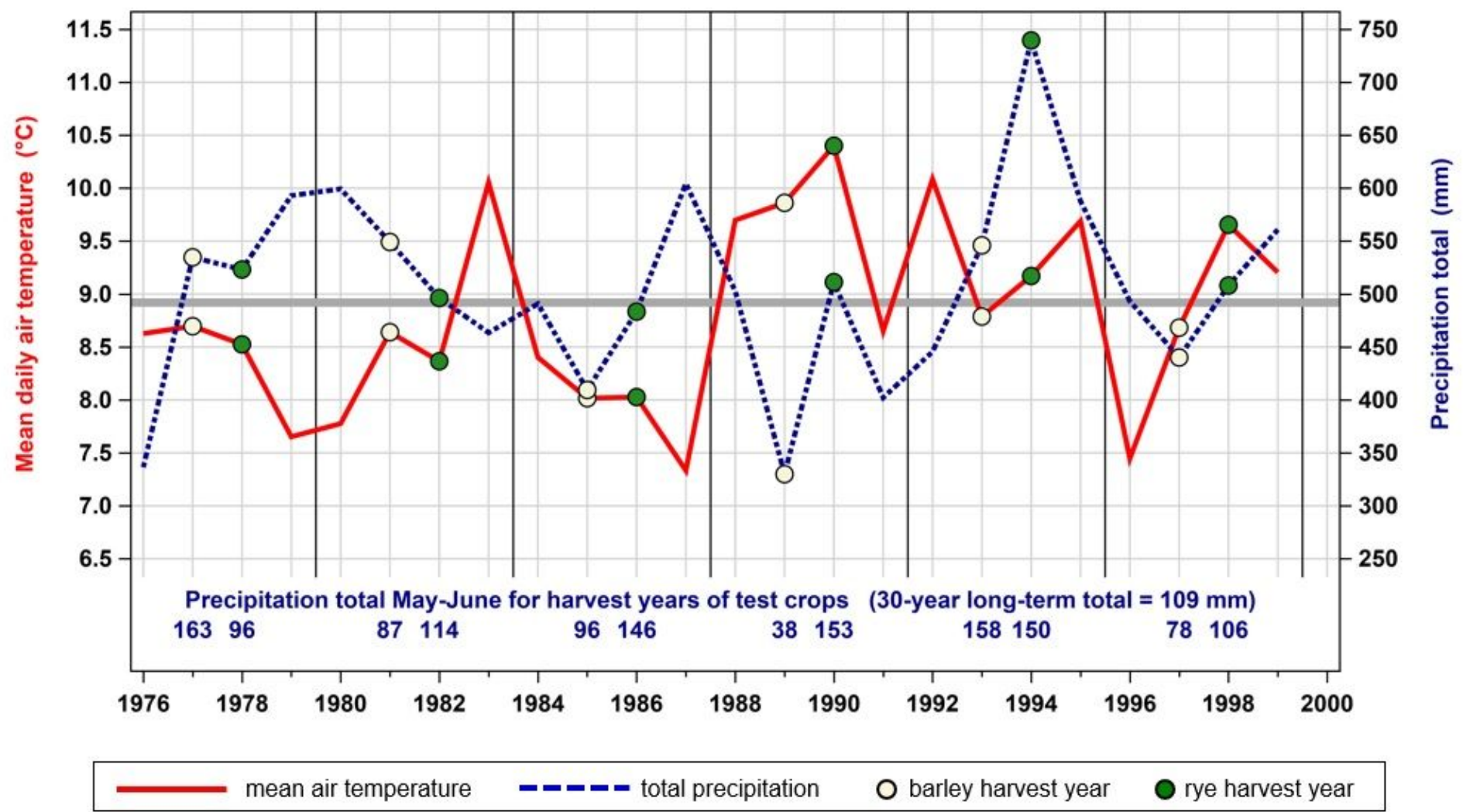

Figure 2 
Mean daily air temperature $\left({ }^{\circ} \mathrm{C}\right)$ and total precipitation $(\mathrm{mm})$ of growing seasons (September of preceding year - August of harvest year) at the experimental site Thyrow. Reference line symbolizes the corresponding 30 -year long-term average of annual mean temperature $\left(8.87^{\circ} \mathrm{C}\right)$ and total annual precipitation $(497 \mathrm{~mm})$ for the period 1971-2000.

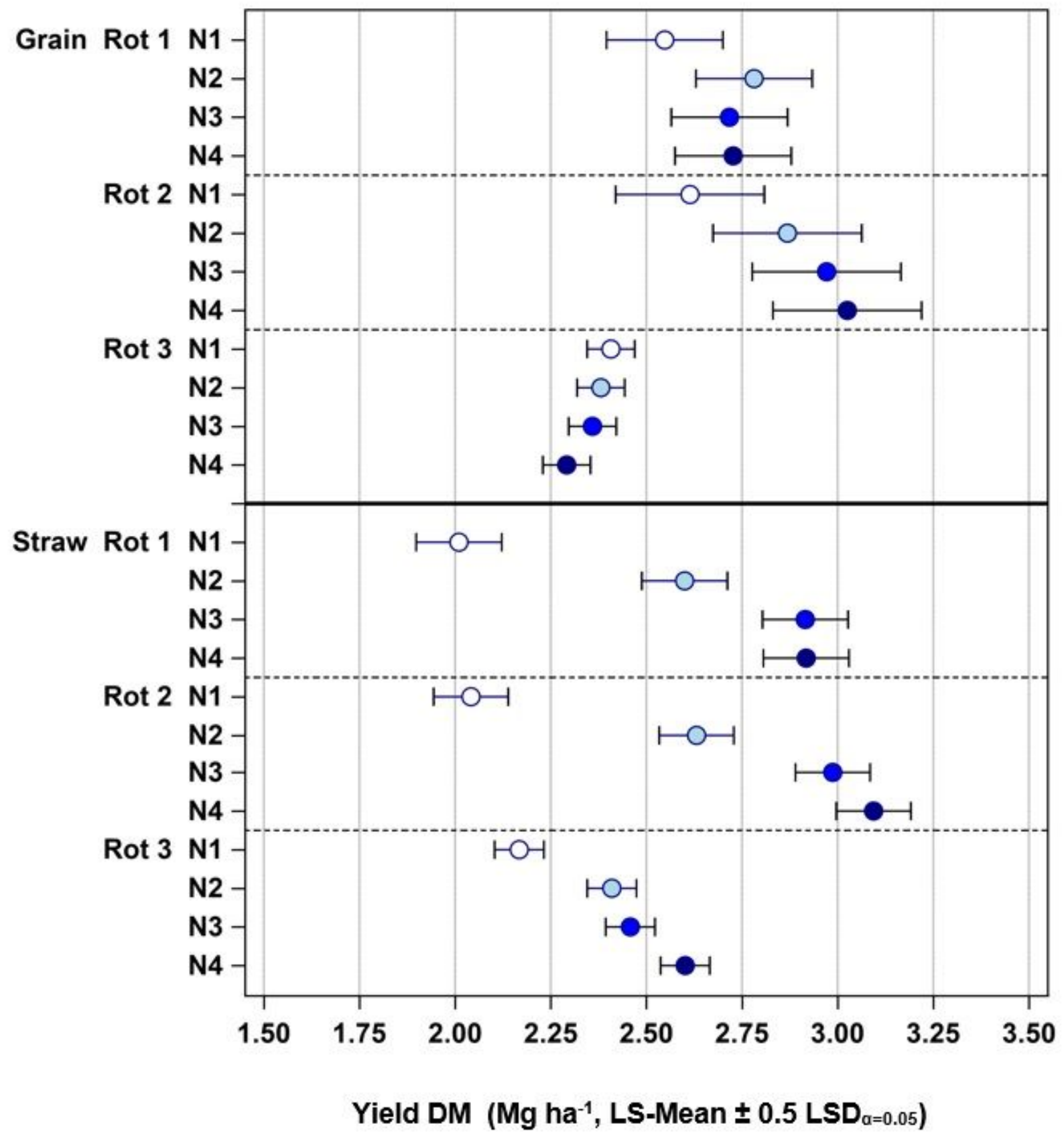

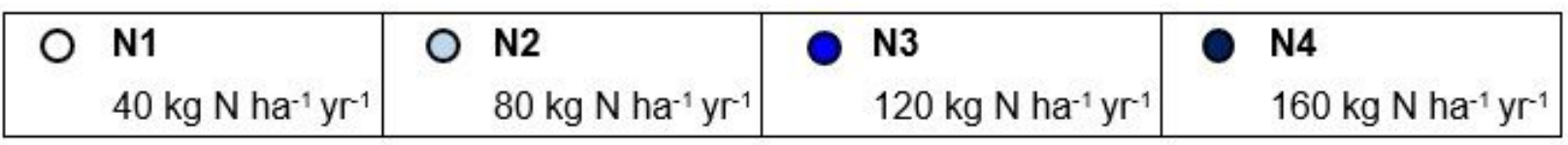

Figure 3 
Grain and straw yields (DM Mg ha-1) of barley, respectively, from LTE Thy_D5 for period 1976-1999. Pairwise comparisons between nitrogen fertilization treatments per rotation, averaged over straw levels and cycles, n=2. For detailed description of nitrogen fertilization treatments, see Table 1.

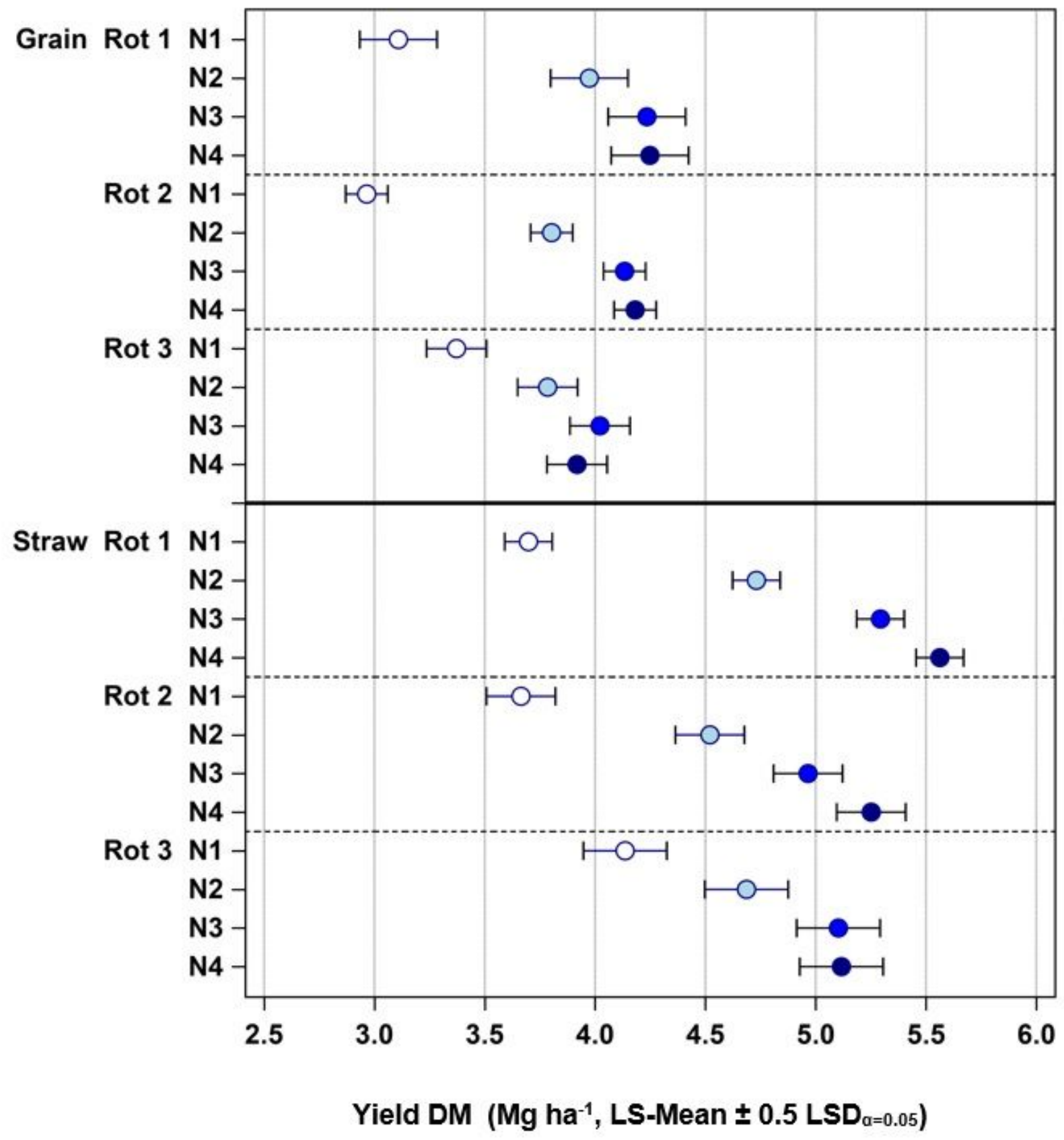

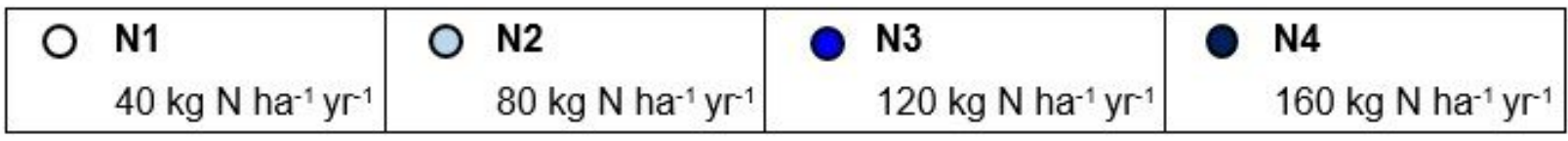

Figure 4 
Grain and straw yields (DM Mg ha-1) of rye, respectively, from LTE Thy_D5 for period 1976-1999. Pairwise comparisons between nitrogen fertilization treatments per rotation, averaged over straw levels and cycles, $\mathrm{n}=2$. For detailed description of nitrogen fertilization treatments, see Table 1.

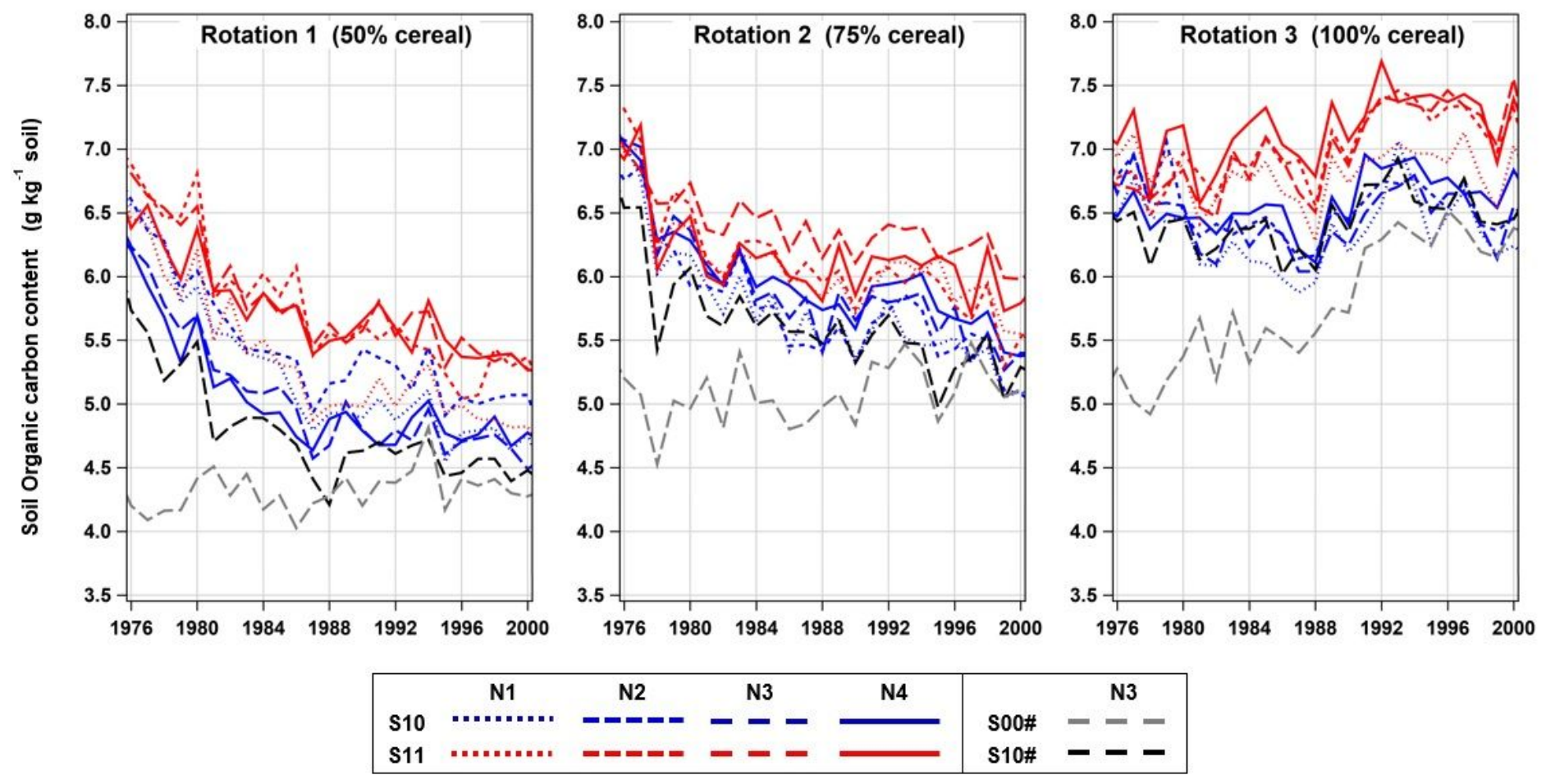

Figure 5

Development of soil organic carbon content per rotation from LTE Thy_D5 in time for the period 19761999. Mean values per treatment and year, $n=2$. For detailed description of treatments, see Table 1 . 
Rotation 1 ( $50 \%$ cereals)

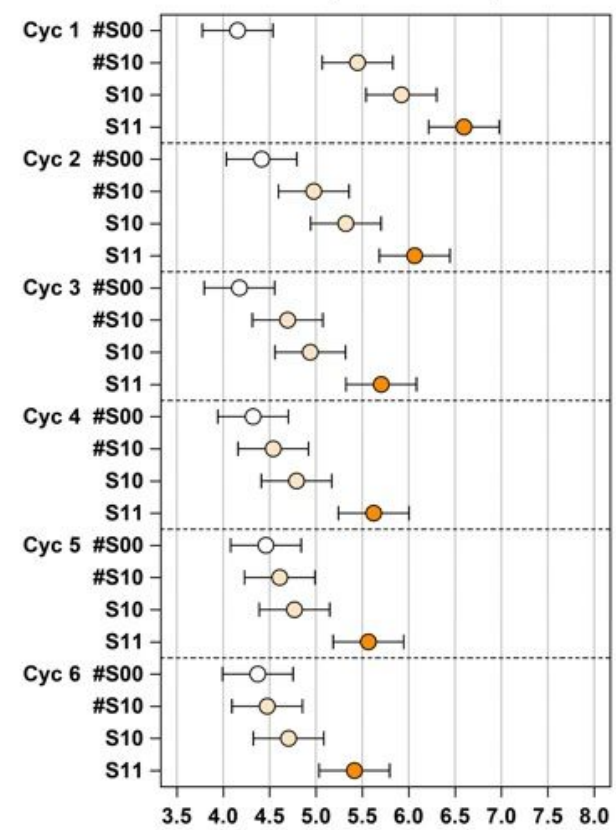

Rotation 2 (75\% cereals)

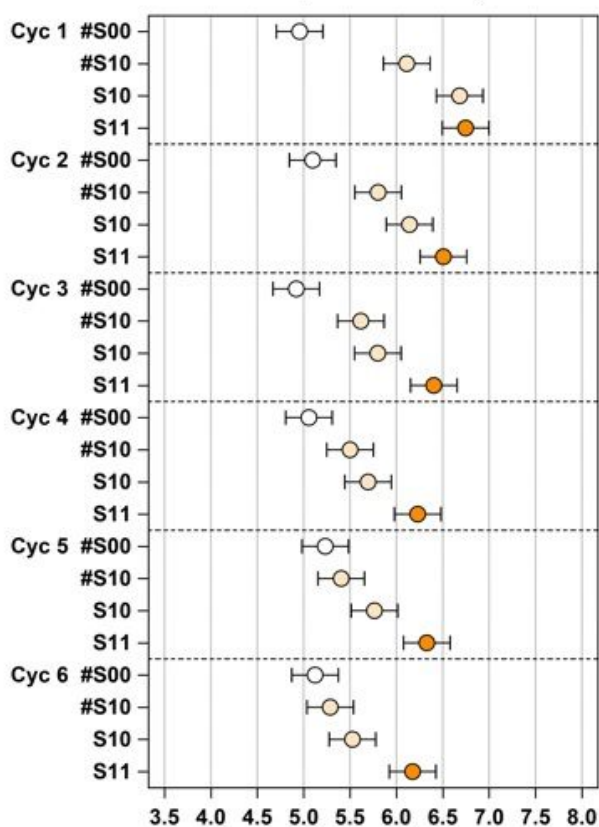

Rotation 3 ( $100 \%$ cereals)

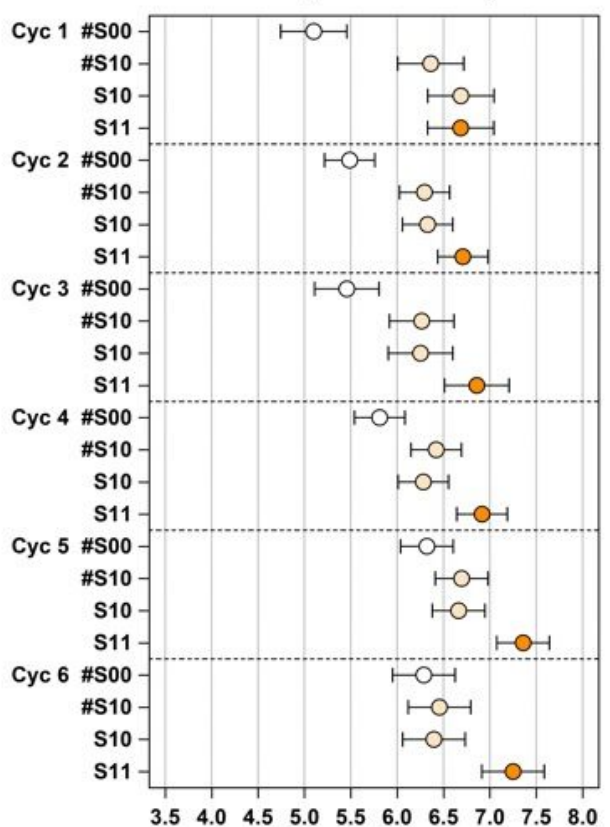

Soil Organic carbon content $\left(\mathrm{g} \mathrm{kg}^{-1}\right.$ soil, LS-Mean $\pm 0.5 \mathrm{LSD}_{\mathrm{a}=0.05}$ )

\begin{tabular}{|l|l|l|}
\hline O $\begin{array}{l}\text { S00\# } \\
\text { no organic manure } \\
\text { since } 1937\end{array}$ & O $\begin{array}{l}\text { S10\#, S10 } \\
\text { until 1971 FYM, } \\
\text { since then no organic manure }\end{array}$ & O $\begin{array}{l}\text { S11 } \\
\text { until 1971 FYM, } \\
\text { since then straw return }\end{array}$ \\
\hline
\end{tabular}

\section{Figure 6}

Soil organic carbon content (treatment means per cycle) from LTE Thy_D5 for the period 1976-1999.

Pairwise comparisons between straw application treatments per rotation and cycle (Cyc), combined with $120 \mathrm{~kg} \mathrm{~N} \mathrm{ha}^{-1} \mathrm{yr}^{-1}$ only, $\mathrm{n}=2$. For detailed description of straw application treatments, see Table 1. 

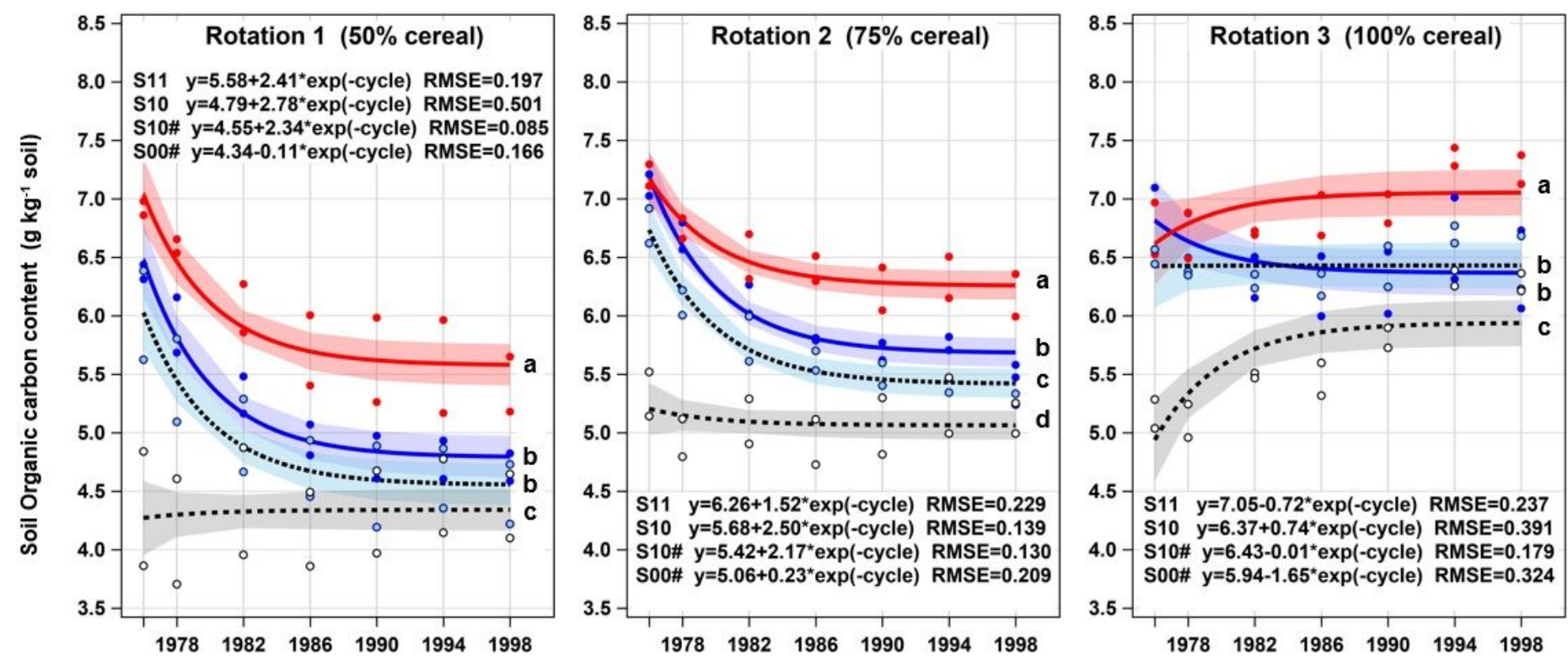

\begin{tabular}{|ccccc|}
\hline & S00\# & S10\# & S10 & S11 \\
N3 & $\ldots \ldots \ldots \ldots$ & $\ldots \ldots \ldots \ldots$ & &
\end{tabular}

\section{Figure 7}

Long-term trend of LS-Means for soil organic carbon content per rotation (treatment means per cycle) from LTE Thy_D5 for the period 1976-1999 (Cycle=1, ... ,6). Selected straw application treatments, combined with $120 \mathrm{~kg} \mathrm{~N} \mathrm{ha}^{-1} \mathrm{yr}^{-1}$ only, $\mathrm{n}=2$. For detailed description of straw application treatments, see Table 1.

Pairwise comparison of treatments for final cycle 6: LS-Means with no letters in common are different $\left(\operatorname{LSD}_{\mathrm{a}=0.05}\right)$.

\section{Supplementary Files}

This is a list of supplementary files associated with this preprint. Click to download.

- PaperD5ThyKroschewskietal2021Supplemental.docx 